\title{
EVALUATION OF PUBLIC KNOWLEDGE AND BELIEFS OF ADVERSE HEALTH EFFECTS OF UNHEALTHY FOOD AND KNOWLEDGE AND BELIEFS BASED INEQUALITIES AMONG VARIOUS SOCIO- DEMOGRAPHIC GROUPS IN LITHUANIA
}

\author{
Žymantas Žandaras ${ }^{1}$, Valerij Dobrovolskij', Rūta Maceinaitė', Birutė Strukčinskienè ${ }^{2}$, Rokas Arlauskas', \\ Rimantas Stukas ${ }^{1}$ \\ ${ }^{1}$ Department of Public Health, Institute of Health Sciences, Faculty of Medicine, Vilnius University, Vilnius, Lithuania \\ ${ }^{2}$ Department of Public Health, Faculty of Health Sciences, Klaipeda University, Klaipeda, Lithuania
}

\section{SUMMARY}

Objectives: The availability of information on healthy products does not ensure the empowerment of people with the knowledge on how to choose or avoid food products or dishes depending on unhealthy factors. Public knowledge and beliefs of unhealthy food effects on health needs to be evaluated so that appropriate measures can be taken to properly inform people and relevant socio-demographic groups.

Methods: The original survey questionnaire containing questions about specific food groups and various health effects was compiled. A total of 1,007 respondents, Lithuanian residents aged 18-75 years, were surveyed in March 2019. Multilevel stratified probability sampling method was used for data representativeness.

Results: Almost half of respondents (46.2\%) knew that deep-fried food could cause cancer. The majority of respondents (68.4\%) were aware that sugar causes obesity and $61.7 \%$ were aware that sugar increases the risk of diabetes mellitus; $41.6 \%$ (more often those living in non-rural areas) know that grilled meat may cause cancer. More than half of respondents (57.2\%) (more likely those living in non-rural areas and those with a university degree) were aware that smoked meat products may cause cancer. Only $46.4 \%$ were aware of the fact that salt raises blood pressure and the risk of cardiovascular diseases.

Conclusion: Only about half of Lithuanian residents aged 18-75 were aware of the scientifically proven harmful effects of unhealthy food groups. Socio-demographic factors influence the knowledge and beliefs of the population.

Key words: unhealthy food, junk food, knowledge, beliefs

Address for correspondence: Ž. Žandaras, Department of Public Health, Institute of Health Sciences, Faculty of Medicine, Vilnius University, Universiteto St. 3, 01513 Vilnius, Lithuania. E-mail: zymantas.zandaras@mf.vu.It

https://doi.org/10.21101/cejph.a6180

\section{INTRODUCTION}

Unhealthy food increases the risk of obesity, non-communicable diseases such as cancer, cardiovascular diseases, diabetes mellitus, and premature mortality. A wide range of popular food products and dishes may be unhealthy because their ingredients or the substances that form during the food production process may trigger non-communicable diseases (1-4).

Unhealthy foods are commonly considered to be deep-fried food, grilled food, smoked products, foods high in sugar and salt. Their negative effects on health are confirmed by various research results. Most food products for deep frying sold in shops and restaurants are starchy or with a starchy coating, such as fish fingers, chicken nuggets, French fries, potato chips, etc. Starchy food high in carbohydrates when deep-fried in high temperature forms acrylamide which is a carcinogen (5). Some researchers have linked deep-fried food to diabetes mellitus, cardiovascular diseases, high blood cholesterol $(6,7)$, and obesity (8). Grilled foods contain polycyclic aromatic hydrocarbons (9) and heterocyclic aromatic amines (10), which are carcinogens (11). Carcinogenic substances (polycyclic aromatic hydrocarbons (benzo (a) pyrene) is released by smouldering wood to food when meat, fish or other products are smoked $(11,12)$. However, it is worth noting that benzo (a) pyrene is not associated with liver cancer (13). Salt raises blood pressure and the risk of cardiovascular diseases (14). It is known that high sugar intake is associated with obesity (15-19) and diabetes mellitus (20). Scientists also associate sugar consumption with liver damage and liver diseases (21-23). Some studies show that people who like salty foods have a higher risk of stomach cancer (24-26) although some research reviews deny this claim (27). The influence of salt on gastric cancer is related to the influence of $\mathrm{H}$. pylori on gastric cancer (26) and 
therefore this study only considers it as an indirect effect of salt on gastric cancer.

Non-communicable diseases prevention, health promotion, educational programmes, social networks, and media highlight information on what healthy food and healthy nutrition is, what to eat and what to avoid, or how to cook healthy meals (1-3). Informing the public about healthy nutrition usually does not overlook what food products and dishes are unhealthy, however, there is a lack of emphasis on how and why such food products are likely to cause non-infectious diseases. Without getting sufficient information why certain foods are unhealthy, on the one hand, people tend to be afraid or avoid particular food products, on the other hand, they may select food products by themselves by labels and substances or ingredients they are composed of, what may pose risks to their health and trigger non-infectious diseases.

Unfortunately, no recent studies have been found that would investigate the public knowledge and beliefs on the negative health effects of popular food products and dishes which contain ingredients or substances that form during the production process and that may be a cause of non-communicable diseases. Due to a lack of information or its diversity in the society, myths are formed and the society focuses only on specific groups of generic foods (generic names of dishes and products) and not on the ingredients or production technology of a particular product. Without knowing the public knowledge and beliefs about the risk of unhealthy food products and without knowing the knowledge and beliefs differences between the different socio-demographic groups, it would be wrong to implement health and educational programmes or media campaigns. It is important to know and take into account relevant socio-demographic groups, their specific knowledge and beliefs of unhealthy food products, and their impact on health in order to achieve the results of the targeted campaign and programme. Such information will enable the development of appropriate and effective nutrition policies in countries, educational and informative programmes and campaigns that can, in the long term, adequately enable the people to select foods based on their ingredients and production technologies. The lack of such information determined the purpose of the study - to evaluate knowledge and beliefs of adverse health effects of unhealthy food and knowledge- and beliefs-based inequalities among various socio-demographic groups in Lithuania.

\section{MATERIALS AND METHODS}

The original survey questionnaire with questions about specific food groups and various health effects was compiled. Unhealthy foods were divided into five groups according to their composition and adverse health effects (deep-fried food, sugar and sweet pastry, grilled food, smoked products, salt and salty food). Such food groups are often selected in Lithuania when conducting research on unhealthy food consumption habits. A total of 1,007 respondents, Lithuania's residents aged 18-75 years, were surveyed in March 2019. The survey was conducted by a professional market and public opinion research company using a multilevel stratified probability sampling method that provides data representativeness, i.e. each household in the country has an equal opportunity to be surveyed and the target population corresponds to the target population according to target criteria. The results of the study represent the knowledge and beliefs of all regions of the country and the population within the age range of 18-75.

Stata and WinPepi statistical programs were used for statistical processing of the data. $95 \%$ CIs were calculated for prevalence estimates. To find out what socio-demographic factors have a significant impact on the respondents' knowledge and beliefs of the health effects of various unhealthy foods, the Pearson Chi square test was used to analyze the data. The difference was considered statistically significant at $\mathrm{p} \leq 0.05$.

The respondents were grouped by gender, age, education, income, and place of residence (Table 1).

\section{RESULTS}

\section{Knowledge and Beliefs about Unhealthy Food}

The results of the study show that more than half of those surveyed $(55.9 \%)$ knew that deep-fried food is the reason of overweight and obesity, $50 \%$ of the respondents claim that these products increase blood cholesterol, and $46.2 \%$ believe that deep-fried food can cause cancer. The results of the survey also reveal that the majority of the population knew that sugar and sweet pastry increase the risk of diabetes mellitus and cause overweight and obesity ( $68.4 \%$ and $61.7 \%$, respectively). Nearly half of the respondents $(46.4 \%)$ were aware that salt and salty foods increase blood pressure and can cause cardiovascular diseases. According to the respondents, grilled meat and smoked products are associated with cancer $(41.6 \%$ and $57.2 \%$, respectively) (Table 2).

Table 1. Characteristics of respondents $(N=1,007)$

\begin{tabular}{|c|c|c|}
\hline & $\mathrm{n}$ & $\%$ \\
\hline \multicolumn{3}{|l|}{ Gender } \\
\hline Male & 476 & 47.3 \\
\hline Female & 531 & 52.7 \\
\hline \multicolumn{3}{|l|}{ Age } \\
\hline Less than 45 years & 517 & 51.3 \\
\hline 45 years and more & 490 & 48.7 \\
\hline \multicolumn{3}{|l|}{ Place of residence } \\
\hline Rural area (up to 500 residents) & 297 & 29.5 \\
\hline $\begin{array}{l}\text { Small town (between } 500 \text { and 100,000 } \\
\text { residents) }\end{array}$ & 276 & 27.4 \\
\hline Big city (more than 100,000 residents) & 434 & 43.1 \\
\hline \multicolumn{3}{|l|}{ Education } \\
\hline No university degree & 629 & 62.5 \\
\hline University degree & 378 & 37.5 \\
\hline \multicolumn{3}{|l|}{ Income (netto) per month } \\
\hline $700 €$ and less & 574 & 57.0 \\
\hline More than $700 €$ & 433 & 43.0 \\
\hline
\end{tabular}


Table 2. Distribution of respondents according to their knowledge and beliefs of effects of unhealthy food on people's health $(N=1,007)$

\begin{tabular}{|c|c|c|c|c|c|c|c|c|}
\hline Food group & $\begin{array}{c}\text { Increases } \\
\text { blood } \\
\text { cholesterol } \\
\% \\
95 \% \mathrm{Cl}\end{array}$ & $\begin{array}{c}\text { Increases } \\
\text { blood } \\
\text { pressure, can } \\
\text { cause cardio- } \\
\text { vascular } \\
\text { diseases } \\
\% \\
95 \% \mathrm{Cl}\end{array}$ & $\begin{array}{c}\text { Increases risk } \\
\text { of diabetes } \\
\text { mellitus } \\
\% \\
95 \% \mathrm{Cl}\end{array}$ & $\begin{array}{c}\text { Causes over- } \\
\text { weight and } \\
\text { obesity } \\
\% \\
95 \% \mathrm{Cl}\end{array}$ & $\begin{array}{c}\text { Increases risk } \\
\text { of cancer } \\
\% \\
95 \% \mathrm{Cl}\end{array}$ & $\begin{array}{c}\text { May cause } \\
\text { liver damage } \\
\% \\
95 \% \mathrm{Cl}\end{array}$ & $\begin{array}{c}\text { Has no nega- } \\
\text { tive effects on } \\
\text { health } \\
\% \\
95 \% \mathrm{Cl}\end{array}$ & $\begin{array}{c}\text { Unaware of } \\
\text { effects on } \\
\text { health } \\
\% \\
95 \% \mathrm{Cl}\end{array}$ \\
\hline $\begin{array}{l}\text { Deep-fried } \\
\text { food }\end{array}$ & $\begin{array}{c}50.0 \\
47.0-53.1\end{array}$ & $\begin{array}{c}38.1 \\
35.2-41.2\end{array}$ & $\begin{array}{c}26.0 \\
23.4-28.8\end{array}$ & $\begin{array}{c}55.9 \\
52.8-59.0\end{array}$ & $\begin{array}{c}46.2 \\
43.1-49.3\end{array}$ & $\begin{array}{c}40.3 \\
37.3-43.4\end{array}$ & $\begin{array}{c}1.9 \\
1.2-2.9\end{array}$ & $\begin{array}{c}4.7 \\
3.5-6.2\end{array}$ \\
\hline $\begin{array}{l}\text { Sugar, sweet } \\
\text { pastry }\end{array}$ & $\begin{array}{c}33.0 \\
30.1-35.9\end{array}$ & $\begin{array}{c}24.9 \\
22.4-27.7\end{array}$ & $\begin{array}{c}68.4 \\
65.5-71.2\end{array}$ & $\begin{array}{c}61.7 \\
58.6-64.6\end{array}$ & $\begin{array}{c}23.3 \\
20.8-26.1\end{array}$ & $\begin{array}{c}21.3 \\
18.8-23.9\end{array}$ & $\begin{array}{c}1.8 \\
1.1-2.8\end{array}$ & $\begin{array}{c}4.2 \\
3.1-5.6\end{array}$ \\
\hline Grilled food & $\begin{array}{c}30.9 \\
28.1-33.8\end{array}$ & $\begin{array}{c}26.1 \\
23.5-28.9\end{array}$ & $\begin{array}{c}9.9 \\
8.2-11.9\end{array}$ & $\begin{array}{c}17.6 \\
15.4-20.1\end{array}$ & $\begin{array}{c}41.6 \\
38.6-44.7\end{array}$ & $\begin{array}{c}30.6 \\
27.8-33.5\end{array}$ & $\begin{array}{c}12.5 \\
10.6-14.7\end{array}$ & $\begin{array}{c}8.6 \\
7.1-10.5\end{array}$ \\
\hline $\begin{array}{l}\text { Smoked } \\
\text { products }\end{array}$ & $\begin{array}{c}33.6 \\
30.7-36.5\end{array}$ & $\begin{array}{c}40.4 \\
37.4-43.5\end{array}$ & $\begin{array}{c}11.9 \\
10.1-14.1\end{array}$ & $\begin{array}{c}24.1 \\
21.6-26.9\end{array}$ & $\begin{array}{c}57.2 \\
54.1-60.2\end{array}$ & $\begin{array}{c}33.6 \\
30.7-36.5\end{array}$ & $\begin{array}{c}5.4 \\
4.1-6.9\end{array}$ & $\begin{array}{c}6.1 \\
4.7-7.7\end{array}$ \\
\hline $\begin{array}{l}\text { Salt, salty } \\
\text { products }\end{array}$ & $\begin{array}{c}15.7 \\
13.6-18.1\end{array}$ & $\begin{array}{c}46.4 \\
43.3-49.5\end{array}$ & $\begin{array}{c}9.3 \\
7.7-11.3\end{array}$ & $\begin{array}{c}14.1 \\
12.1-16.4\end{array}$ & $\begin{array}{c}9.3 \\
7.7-11.3\end{array}$ & $\begin{array}{c}16.2 \\
14.1-18.6\end{array}$ & $\begin{array}{c}10.5 \\
8.8-12.6\end{array}$ & $\begin{array}{c}12.5 \\
10.6-14.7\end{array}$ \\
\hline
\end{tabular}

\section{Knowledge and Beliefs among Various Socio-demo- graphic Groups}

When evaluating the distribution of respondents according to their knowledge and beliefs of the effects of deep-fried food on health, statistically significant differences were found between men and women across socio-demographic groups. More women than men indicated that those products increased the levels of cholesterol, blood pressure and diabetes mellitus, could cause cancer, liver damage, and obesity. Significantly more respondents with a university degree knew and indicated that deep-fried food caused overweight and obesity ( $60.6 \%$ and $53.1 \%$, respectively), while more respondents without university degree associated deep-fried food with the increased blood pressure and cardiovascular diseases (40.7\% and $33.9 \%$, respectively) (Table 3 ).

The analysis of the distribution of respondents according to their knowledge and beliefs of the effects of sugar and sweet pastry products on people's health showed significant differences between men and women: more women (35.8\%) than men (29.8\%) believed that those products increased cholesterol levels, caused overweight and obesity ( $67.4 \%$ and $55.3 \%$, respectively) or could cause cancer (26.2\% and $20.2 \%$, respectively). We also found that a significantly higher proportion of younger respondents thought that the use of those products increased blood pressure and the risk of cardiovascular diseases (27.7\% and $22.0 \%$, respectively) (Table 3 ).

The evaluation of the distribution of respondents based on their knowledge and beliefs of the impact of grilled food on people's health in different socio-demographic groups, significant differences were found between males and females (a statistically significant difference was observed between gender groups - more females than males believed that consumption of grilled food increased blood cholesterol (33.7\% and $27.7 \%$, respectively) and could lead to liver damage (33.7\% and $27.1 \%$, respectively). More respondents with non-university degree claimed that grilled food increased blood cholesterol levels and the risk of diabetes mellitus. Also, significantly more respondents with higher education (47.4\%) were aware of the association of the consumption of grilled food and the risk of cancer compared to respondents without a university degree (38.2\%) (Table 3).

A statistically significant relationship was found between the respondents' knowledge that smoked products are likely to increase blood pressure and cause cardiovascular diseases, and their gender, place of residence, age and income (positive responses were given by significantly more women, residents of small cities, and those older than 45 years and with a lower income). We also found that the respondents' knowledge that smoked products could cause cancer was significantly associated with the place of residence. The proportion of residents who were aware that smoked products may increase the chance of cancer was significantly higher in small towns $(64.1 \%)$ and in large cities (56.5\%) than in rural areas $(51.9 \%)$ (Table 3$)$.

Statistically significant differences were found between different age groups in evaluating the distribution of respondents based on their knowledge and beliefs of the effect of salt on health. The respondents over the age of 45 knew that salt and salty foods could increase blood pressure and cause cardiovascular diseases than the respondents younger than 45 years of age $(52.4 \%$ and $40.6 \%$, respectively). More of the younger respondents (16.6\%) were unaware of the health effects of salt compared to older respondents $(8.2 \%)$. Significantly more respondents without a university degree believed that salt could cause cancer, liver damage, increased risk of diabetes mellitus, overweight and obesity compared to those with a university degree (Table 3 ).

\section{DISCUSSION}

This was the first study in Lithuania that aimed to evaluate knowledge and beliefs of adverse health effects of unhealthy food and knowledge- and beliefs-based inequalities among various socio-demographic groups. The results of this study showed that it is necessary to provide people more information about adverse health effects of unhealthy food. 


\begin{tabular}{|c|c|c|c|c|c|c|c|c|c|c|c|c|c|c|c|c|c|c|c|}
\hline & 全 & 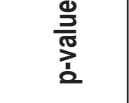 & $\stackrel{ }{\circ}$ & 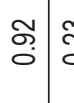 & 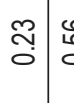 & 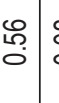 & \begin{tabular}{l|l}
8 \\
0
\end{tabular} & $\begin{array}{l} \\
\dot{0}\end{array}$ & $\frac{0}{6}$ & $\begin{array}{l}\bar{\delta} \\
\dot{0} \\
v\end{array}$ & $\begin{array}{c}0 \\
0 \\
0\end{array}$ & f & $\stackrel{\Xi}{\circ}$ & $\bar{\delta}: \stackrel{\text { s. }}{c}$ & $\begin{array}{l}\text { : } \\
0\end{array}$ & 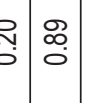 & $\mid \begin{array}{l}\infty \\
\infty \\
\infty \\
0\end{array}$ & $\left|\begin{array}{c}\infty \\
\hdashline \\
\hdashline\end{array}\right|$ & 冓 \\
\hline & 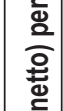 & 总 怘 & $\left|\begin{array}{l}0 \\
\dot{f} \\
\dot{f}\end{array}\right|$ & \begin{tabular}{l|l} 
& 0 \\
$\tilde{ల}$ & $\vdots$
\end{tabular} & 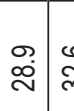 & $\begin{array}{l}0 \\
\stackrel{m}{m}\end{array}$ & 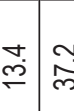 & 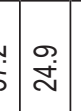 & Oे & 灾 & \begin{tabular}{l|l}
0 \\
$\dot{c}$ \\
$\dot{\sigma}$
\end{tabular} & $\begin{array}{l}\pi \\
\tilde{6}\end{array}$ & $\infty_{\infty}^{\infty}$ & $\left.\stackrel{m}{F}\right|_{\alpha} ^{\infty}$ & 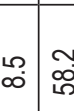 & 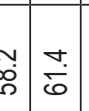 & $\stackrel{\Re}{\stackrel{\sim}{\leftarrow}}$ & $\mid$ & 官 \\
\hline & 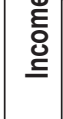 & 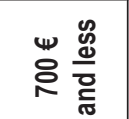 & 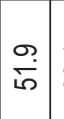 & $\bar{m}$ & 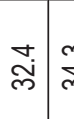 & $\stackrel{m}{m}$ & \begin{tabular}{l|l}
$\stackrel{D}{*}$ \\
$\stackrel{\sim}{*}$
\end{tabular} & $\dot{j}$ & $\stackrel{\curvearrowright}{\sim}$ & $\underset{j}{\dot{J}}$ & \begin{tabular}{c|c}
$\hat{\sigma}$ \\
$\dot{q}$
\end{tabular} & $\begin{array}{l}m \\
\ddot{8}\end{array}$ & 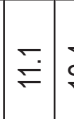 & 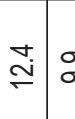 & $\stackrel{g}{\sigma})$ & 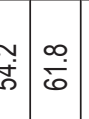 & $\stackrel{\infty}{\stackrel{\infty}{F}}$ & $\stackrel{+}{\stackrel{i}{N}}$ & $\underset{\dot{I}}{\stackrel{0}{+}}$ \\
\hline & & 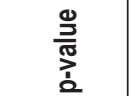 & Эั & 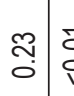 & 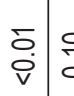 & $\stackrel{\circ}{\circ}$ & 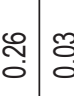 & $\begin{array}{l}3 \\
\text { s. }\end{array}$ & $\mid \begin{array}{l}0 \\
0 \\
0\end{array}$ & \begin{tabular}{l|l}
$\tilde{O}$ \\
\hdashline
\end{tabular} & 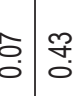 & $\begin{array}{l}8 \\
8 \\
0\end{array}$ & $\begin{array}{l}\overline{0} \\
\dot{i} \\
v\end{array}$ & \begin{tabular}{c|c}
$\bar{c}$ \\
$\bar{c}$ \\
$\bar{c}$
\end{tabular} & 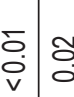 & 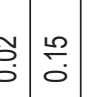 & $\tilde{O}$ & \begin{tabular}{l|}
$\infty$ \\
$\infty$ \\
$\infty$ \\
0
\end{tabular} & 范 \\
\hline & 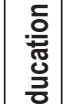 & 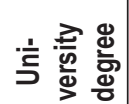 & 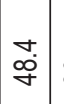 & $\hat{\dot{m}}$ & $\stackrel{\sim}{\sim} \mid$ & 今ें & \begin{tabular}{l|l}
$\stackrel{\circ}{+}$ & $\stackrel{m}{m}$ \\
\end{tabular} & \begin{tabular}{l|l}
$\dot{p}$ \\
$\dot{j}$
\end{tabular} & 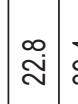 & 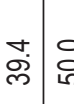 & 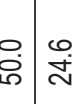 & \begin{tabular}{|l|}
2 \\
$\infty$ \\
0 \\
0
\end{tabular} & \begin{tabular}{l|l}
$\infty$ \\
0
\end{tabular} & \begin{tabular}{l|l}
$L$ & $\mathbb{L}$ \\
$\infty$ &
\end{tabular} & 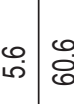 & 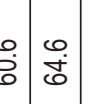 & \begin{tabular}{|l|}
$\stackrel{\rho}{\rho}$ \\
$\stackrel{\rho}{\rho}$
\end{tabular} & $\begin{array}{l}\infty \\
\tilde{\sim} \\
\tilde{N}\end{array}$ & $\check{F}$ \\
\hline & & 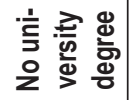 & 움 & $\stackrel{m}{\stackrel{m}{p}}$ & 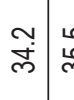 & 资 & \begin{tabular}{l|l}
$\hat{0}$ & $\hat{q}$
\end{tabular} & 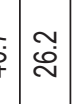 & $\check{\infty}$ & $\stackrel{\circ}{\dot{\forall}} \rightrightarrows$ & 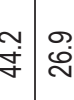 & $\begin{array}{l}0 \\
\infty \\
0 \\
0\end{array}$ & $\overline{\check{I}}$ & 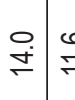 & $\stackrel{\leftrightarrow}{=}$ & 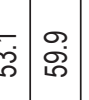 & $\mid \begin{array}{l}\infty \\
\stackrel{\infty}{\leftarrow}\end{array}$ & 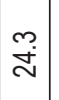 & 官 \\
\hline & & $\frac{\stackrel{0}{\underline{\pi}}}{\frac{\pi}{\grave{z}}}$ & $\mid \begin{array}{l}0 \\
0 \\
0\end{array}$ & \begin{tabular}{l|l}
8 \\
0 & 5 \\
$c$
\end{tabular} & 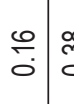 & 孞 & 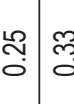 & ?̦ & 空 & 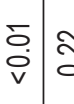 & 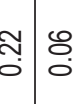 & 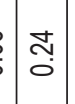 & 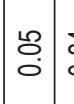 & 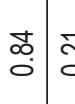 & \begin{tabular}{c|c}
$\bar{ָ}$ & 0 \\
0 & 0 \\
0
\end{tabular} & : & 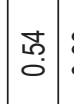 & : & ס \\
\hline 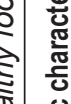 & 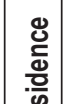 & $\begin{array}{l}\text { 릉 } \\
\text {.0 }\end{array}$ & $\left|\begin{array}{l}\infty \\
o \\
o \\
q \\
q\end{array}\right|$ & $\stackrel{m}{\stackrel{\sim}{\sim}}$ & $\underset{\sim}{\stackrel{\sim}{\sim}}$ & 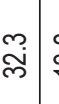 & 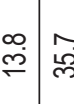 & jo & 守 & 兄 ‡ & 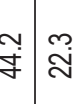 & $\begin{array}{l}0 \\
0 \\
0 \\
0\end{array}$ & $\stackrel{\leftrightarrow}{\sim}$ & $\stackrel{\infty}{F} \mid \mathbb{i}$ & \begin{tabular}{l|l}
$\stackrel{0}{r}$ & $\infty$ \\
in
\end{tabular} & 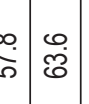 & 它 & $\stackrel{\sim}{\sim}$ & 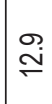 \\
\hline 름 & $\begin{array}{l}0 \\
\dot{\Xi} \\
\frac{\pi}{0} \\
\frac{\pi}{\alpha}\end{array}$ & 丞 & 立 & 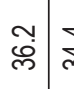 & 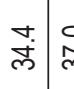 & 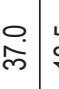 & 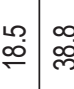 & $\begin{array}{ll}0 \\
\dot{3}\end{array}$ & $\stackrel{m}{\stackrel{\sim}{\sim}}$ & \begin{tabular}{ll}
\multirow{g}{*}{} \\
is
\end{tabular} & 论 & $\overline{\mathbf{N}}$ & $\overline{\dot{O}}$ & 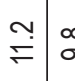 & \begin{tabular}{l|l}
$\infty$ & 0 \\
\hdashline & 0 \\
0 & 0 \\
6
\end{tabular} & 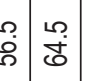 & $\stackrel{+}{\stackrel{*}{*}}$ & $\stackrel{\oplus}{\tilde{\nu}}$ & शे. \\
\hline \& & & 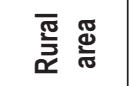 & ฉָ' & 芦| & 尺్లి|శి & ్ָలి & 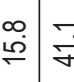 & $\mid \begin{array}{l}\infty \\
\stackrel{\infty}{\infty}\end{array}$ & $\begin{array}{l}0 \\
\stackrel{0}{\sim} \\
\end{array}$ & 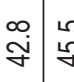 & 年 & $\hat{\imath}$ & $\bar{m}$ & $\stackrel{\infty}{\underset{\sim}{\sim}} \mid \bar{F}$ & \begin{tabular}{l|l}
$\stackrel{+}{E}$ \\
$\stackrel{2}{*}$
\end{tabular} & 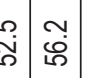 & 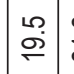 & $\stackrel{\mathcal{I}}{\mathfrak{d}}$ & 要 \\
\hline & & 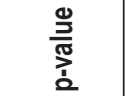 & $\stackrel{5}{0}$ & \begin{tabular}{l|c} 
N \\
O
\end{tabular} & 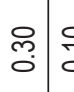 & $\stackrel{\circ}{\circ}$ & \begin{tabular}{c|c}
$\tilde{\sigma}$ & 0 \\
0
\end{tabular} & $\stackrel{0}{0}$ & 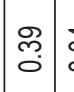 & 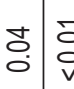 & \begin{tabular}{l|l} 
\\
o. \\
v
\end{tabular} & $\begin{array}{l}0 \\
0\end{array}$ & 吕 & $\stackrel{\circ}{\circ}$ & 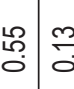 & 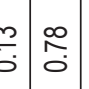 & 志 & $\mid$ & 告 \\
\hline & 娄 & 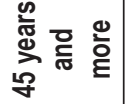 & స્م & \begin{tabular}{l|l}
$\stackrel{p}{\infty}$ & $\overline{\tilde{m}}$ \\
\end{tabular} & 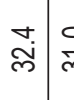 & $\frac{0}{m}$ & $\underset{\oplus}{\underline{6}}$ & j. & 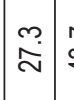 & 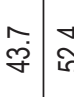 & 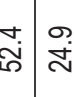 & 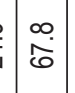 & $\begin{array}{l}\stackrel{0}{0} \\
\stackrel{0}{0}\end{array}$ & 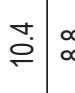 & 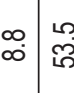 & 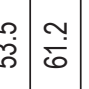 & $\underset{\oplus}{\mathscr{\varphi}}$ & $\stackrel{\Xi}{\sim}$ & $\underset{\sim}{\stackrel{\sim}{+}}$ \\
\hline & & 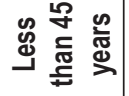 & \begin{tabular}{|l|}
$\infty$ \\
\multirow{\sigma}{*}{} \\
\end{tabular} & $\stackrel{\sim}{\sim} \mid \delta$ & ¿े. & \begin{tabular}{l|l}
$\dot{0}$ & \\
$\dot{m}$ &
\end{tabular} & 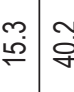 & $\begin{array}{l}\hat{\sim} \\
\vdots\end{array}$ & : & \begin{tabular}{l|l}
$m$ & $\mathscr{c}$ \\
$\stackrel{m}{m}$ & $q$
\end{tabular} & 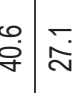 & $\overline{8}$ & $\stackrel{m}{\infty}$ & $\stackrel{m}{\underset{c}{c}}:$ & 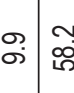 & \begin{tabular}{c|c|c} 
\\
0 \\
0
\end{tabular} & $\stackrel{\circ}{\stackrel{\circ}{\odot}}$ & : & $\stackrel{\widehat{p}}{\rho}$ \\
\hline & & 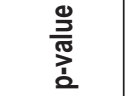 & $\mid \begin{array}{l}\bar{\delta} \\
0 \\
0 \\
v\end{array}$ & to & $\begin{array}{lll}\dot{b} \\
0 \\
0\end{array}$ & \begin{tabular}{l|l}
$\bar{\delta}$ & \\
$\dot{0}$ & \\
$v$ &
\end{tabular} & $\begin{array}{l}\text { Oे } \\
0\end{array}$ & స్ & $\begin{array}{l}\tilde{0} \\
\dot{0} \\
0\end{array}$ & $\begin{array}{ll}\delta \\
\delta\end{array}$ & 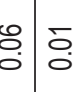 & $\frac{20}{5}$ & \begin{tabular}{|c|c} 
\\
\hdashline \\
0
\end{tabular} & $\stackrel{m}{\circ}$ & 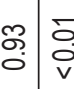 & 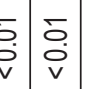 & R & 范 & 守 \\
\hline & 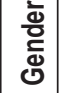 & 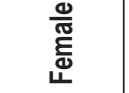 & 芯 & 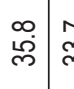 & \begin{tabular}{c|c}
$\hat{m}$ & \multirow{\sigma}{c}{}
\end{tabular} & $\begin{array}{c}\widetilde{m} \\
\widetilde{m}\end{array}$ & 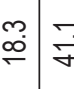 & 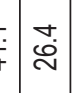 & \begin{tabular}{|c|c}
$\hat{d}$ \\
$\dot{N}$
\end{tabular} & $\begin{array}{l}\text { fo } \\
\dot{f}\end{array}$ & 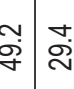 & 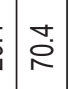 & $\stackrel{\circ}{\circ}$ & 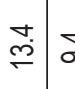 & 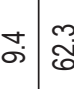 & 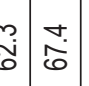 & $\check{\check{F}}$ & 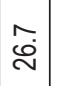 & $\underset{+}{\stackrel{g}{\leftarrow}}$ \\
\hline & & $\frac{\frac{0}{\pi}}{\frac{\pi}{2}}$ & $\hat{\dot{q}}$ & $\begin{array}{l}\infty \\
\stackrel{\sim}{\sim}\end{array}$ & $\stackrel{\sim}{\approx}$ & 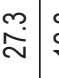 & 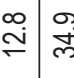 & $\underset{\sim}{\tilde{j}}$ & ڤ્d & $\begin{array}{c}\bar{\phi} \\
\bar{d}\end{array}$ & $\begin{array}{c}m \\
\tilde{y} \\
\tilde{y}\end{array}$ & $\begin{array}{l}\tilde{b} \\
0 \\
0\end{array}$ & $\stackrel{g}{\sigma}$ & $\stackrel{m}{\circ} 0$ & 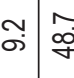 & 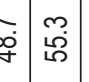 & $\underset{\infty}{\infty}$ & $\stackrel{\sim}{\sim}$ & $\stackrel{\sim}{\sim}$ \\
\hline & & . & 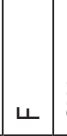 & ॐ & \begin{tabular}{l|c} 
잉 \\
\end{tabular} & के & c & ळ & \begin{tabular}{|l|l} 
寽 & g
\end{tabular} & क & क & ऐo & 采 & क & $\begin{array}{lll}\infty & 4\end{array}$ & 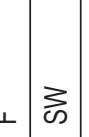 & 采 & के & os \\
\hline & & & & & 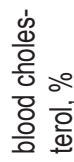 & & & 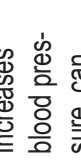 & 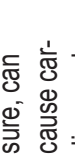 & 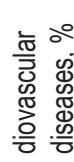 & & & 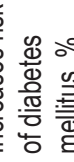 & & & & 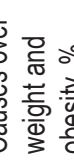 & & \\
\hline
\end{tabular}




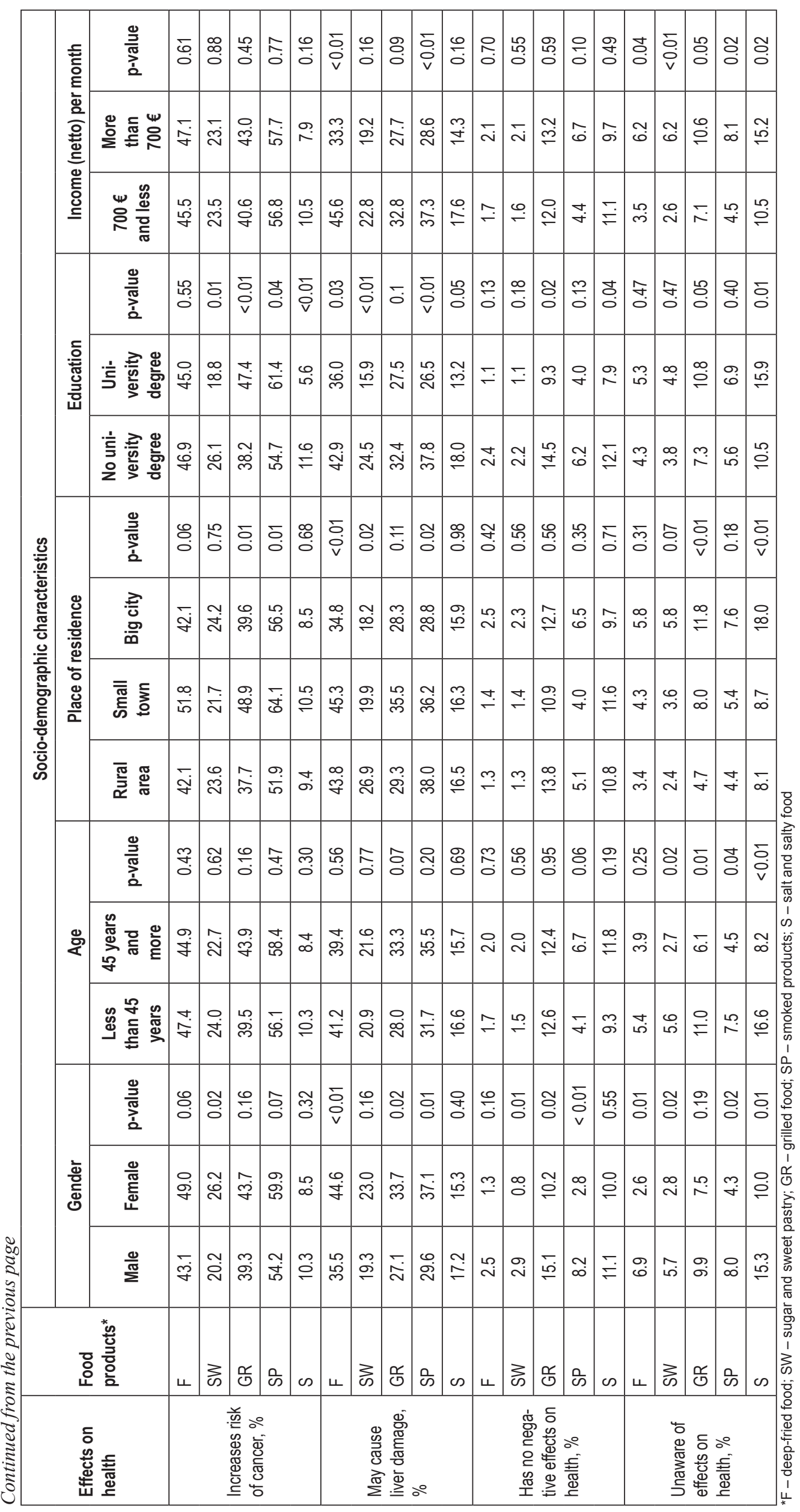


The study showed that only $46.2 \%$ of the respondents knew that deep-fried food could cause cancer. These results may have been due to a lack of knowledge about what deep-fried food may contain. It is possible that people do not know that deep-fried food almost always has starch and when the starch is cooked in high temperatures the acrylamide may form.

Surprisingly, more than half of those surveyed knew that sugar and sweet pastry contributes to overweight and obesity $(61.7 \%$,) and increases the risk of diabetes mellitus $(68.4 \%)$. The fact that a large percentage of people know that sugar consumption is related to weight gain and risk of diabetes mellitus was also found by other researchers (28). Women were significantly more aware of the influence of sugar and sweet pastry on overweight and obesity. This may be due to the fact that women are more inclined to take care of their appearance and therefore know about food that increase the risk of overweight and obesity. The results of a study in India also confirmed that women have better knowledge about the health effects of fast food consumption (29).

It is important to note that although more than $40 \%$ of respondents knew that grilled food could cause cancer and that salt raises blood pressure and the risk of cardiovascular diseases, more than one in ten respondents was mistakenly convinced that grilled food and salty food has no negative effects on health. Such research results demonstrate the need to educate people about the negative health effects of grilled food and salty food. According to other researchers, a significantly higher proportion of people were aware of the effects of salt on hypertension and cardiovascular diseases (30).

Despite the constant media coverage of the carcinogenic effects of substances in smoked foods, only $57.2 \%$ of respondents were aware of the fact. There were significantly more individuals with this knowledge among respondents with higher education. Such results can be explained by the fact that respondents with higher education tend to take more care of their health.

\section{Limitations}

The survey was conducted under varying conditions: some respondents were surveyed by a professional interviewer, while the rest filled out the questionnaires independently. Some respondents may have wanted to appear "better" and seek information on the negative health effects of unhealthy foods while completing questionnaires on their own. The analysis of the knowledge and beliefs of different groups of respondents about the various health effects of unhealthy foods did not take into account the influence of other socio-demographic factors. These factors could have had a slight influence on the results of the study.

\section{CONCLUSIONS}

The results of this study are an important source of information that reveals an acute issue in Lithuanian public health: only about half of Lithuanian residents aged 18-75 years were aware of the scientifically proven adverse health effects of a variety of unhealthy foods. The results also revealed that some sociodemographic factors exert a significant influence on populations knowledge about adverse health effects of unhealthy foods. We believe that the results of this study send a clear message to the policy makers: there is a need to find effective ways of raising public awareness of the scientifically based specific adverse health effects of unhealthy foods and products and that sociodemographic factors must be taken into account when planning public health intervention measures.

\section{Conflict of Interests}

None declared

\section{REFERENCES}

1. Evans AE, Dave J, Tanner A, Duhe S, Condrasky M, Wilson D, et al. Changing the home nutrition environment: effects of a nutrition and media literacy pilot intervention. Fam Community Health. 2006;29(1):43-54.

2. Tobey LN, Manore MM. Social media and nutrition education: the food hero experience. J Nutr Educ Behav. 2014;46(2):128-33.

3. Wakefield MA, Loken B, Hornik RC. Use of mass media campaigns to change health behaviour. Lancet. 2010;376(9748):1261-71.

4. Cecchini M, Sassi F, Lauer JA, Lee YY, Guajardo-Barron V, Chisholm D. Tackling of unhealthy diets, physical inactivity, and obesity: health effectsand cost-effectiveness. Lancet. 2010;376(9754):1775-84.

5. Abramsson-Zetterberg L. Strongly heated carbohydrate-rich food is an overlooked problem in cancer risk evaluation. Food Chem Toxicol. 2018;121:151-5.

6. Cahill LE, Pan A, Chiuve SE, Sun Q, Willett WC, Hu FB, et al. Fried-food consumption and risk of type 2 diabetes and coronary artery disease: a prospective study in 2 cohorts of US women and men. Am J Clin Nutr. 2014;100(2):667-75.

7. Gadiraju TV, Patel Y, Gaziano JM, Djoussé L. Fried food consumption and cardiovascular health: a review of current evidence. Nutrients. 2015;7(10):8424-30.

8. Guallar-Castillón P, Rodríguez-Artalejo F, Fornés NS, Banegas JR, Etxezarreta PA, Ardanaz E, et al. Intake of fried foods is associated with obesity in the cohort of Spanish adults from the European Prospective Investigation into Cancer and Nutrition. Am J Clin Nutr. 2007;86(1):198205

9. Masuda M, Wang Q, Tokumura M, Miyake Y, Amagai T. Simultaneous determination of polycyclic aromatic hydrocarbons and their chlorinated derivatives in grilled foods. Ecotoxicol Environ Saf. 2019;178:188-94.

10. Viegas O, Novo P, Pinto E, Pinho O, Ferreira IM. Effect of charcoal types and grilling conditions on formation of heterocyclic aromatic amines (HAs) and polycyclic aromatic hydrocarbons (PAHs) in grilled muscle foods. Food Chem Toxicol. 2012;50(6):2128-34.

11. Diggs DL, Huderson AC, Harris KL, Myers JN, Banks LD, Rekhadevi $\mathrm{PV}$, et al. Polycyclic aromatic hydrocarbons and digestive tract cancers: a perspective. J Environ Sci Health C Environ Carcinog Ecotoxicol Rev. 2011;29(4):324-57.

12. Gomaa EA, Gray JI, Rabie S, Lopez-Bote C, Booren AM. Polycyclic aromatic hydrocarbons in smoked food products and commercial liquid smoke flavourings. Food Addit Contam. 1993;10(5):503-21.

13. Warshawsky D. Polycyclic aromatic hydrocarbons in carcinogenesis. Environ Health Perspect. 1999;107(4):317-9.

14. Meneton P, Jeunemaitre X, de Wardener HE, MacGregor GA. Links between dietary salt intake, renal salt handling, blood pressure, and cardiovascular diseases. Physiol Rev. 2005;85(2):679-715.

15. Alexander Bentley R, Ruck DJ, Fouts HN. U.S. obesity as delayed effect of excess sugar. Econ Hum Biol. 2020 Jan;36:100818. doi: 10.1016/j. ehb.2019.100818.

16. de Ruyter JC, Olthof MR, Seidell JC, Katan MB. A trial of sugar-free or sugar-sweetened beverages and body weight in children. N Engl J Med. 2012;367(15):1397-406.

17. Twarog JP, Peraj E, Vaknin OS, Russo AT, Woo Baidal JA, Sonneville KR. Consumption of sugar-sweetened beverages and obesity in SNAPeligible children and adolescents. Prim Care Diabetes. 2020;14(2):181-5.

18. Grummon AH, Smith NR, Golden SD, Frerichs L, Taillie LS, Brewer NT. Health warnings on sugar-sweetened beverages: simulation of impacts on diet and obesity among U.S. Adults. Am J Prev Med. 2019;57(6):765-74.

19. Anari R, Amani R, Veissi M. Sugar-sweetened beverages consumption is associated with abdominal obesity risk in diabetic patients. Diabetes Metab Syndr. 2017;11 Suppl 2:S675-8. 
20. Malik VS, Popkin BM, Bray GA, Després JP, Hu FB. Sugar-sweetened beverages, obesity, type 2 diabetes mellitus, and cardiovascular disease risk. Circulation. 2010;121(11):1356-64.

21. Shimony MK, Schliep KC, Schisterman EF, Ahrens KA, Sjaarda LA, Rotman Y, et al. The relationship between sugar-sweetened beverages and liver enzymes among healthy premenopausal women: a prospective cohort study. Eur J Nutr. 2016;55(2):569-76.

22. Jensen T, Abdelmalek MF, Sullivan S, Nadeau KJ, Green M, Roncal C, et al. Fructose and sugar: a major mediator of non-alcoholic fatty liver disease. J Hepatol. 2018;68(5):1063-75.

23. Ma J, Fox CS, Jacques PF, Speliotes EK, Hoffmann U, Smith CE, et al. Sugar-sweetened beverage, diet soda, and fatty liver disease in the Framingham Heart Study cohorts. J Hepatol. 2015;63(2):462-9.

24. Strumylaite L, Zickute J, Dudzevicius J, Dregval L. Salt-preserved foods and risk of gastric cancer. Medicina (Kaunas). 2006;42(2):164-70.

25. D'Elia L, Rossi G, Ippolito R, Cappuccio FP, Strazzullo P. Habitual salt intake and risk of gastric cancer: a meta-analysis of prospective studies. Clin Nutr. 2012;31(4):489-98.

26. Peleteiro B, Lopes C, Figueiredo C, Lunet N. Salt intake and gastric cancer risk according to Helicobacter pylori infection, smoking, tumour site and histological type. Br J Cancer. 2011;104(1):198-207.
27. Wang XQ, Terry PD, Yan H. Review of salt consumption and stomach cancer risk: epidemiological and biological evidence. World J Gastroenterol. 2009;15(18):2204-13.

28. Park S, Lundeen EA, Pan L, Blanck HM. Impact of knowledge of health conditions on sugar-sweetened beverage intake varies among US adults. Am J Health Promot. 2018;32(6):1402-8.

29. Khongrangjem T, Dsouza SM, Prabhu P, Dhange VB, Pari V, Ahirwar SK, et al. A study to assess the knowledge and practice of fast food consumption among pre-university students in Udupi Taluk, Karnataka, India. Clin Epidemiol Global Health. 2018;6(4):172-5.

30. Cheikh Ismail L, Hashim MH, Jarrar AN, Mohamad MT, Saleh S, Jawish $\mathrm{N}$, et al. Knowledge, attitude, and practice on salt and assessment of dietary salt and fat intake among University of Sharjah Students. Nutrients. 2019;11(5):941. doi: 10.3390/nu11050941.

Received March 16, 2020 Accepted in revised form November 18, 2020 